\title{
THRESHOLDS FOR GULLY INITIATION AND SEDIMENTATION IN MEDITERRANEAN EUROPE
}

\author{
L. VANDEKERCKHOVE ${ }^{1}$, J. POESEN ${ }^{1,2}$, D. OOSTWOUD WIJDENES ${ }^{1}{ }^{3}$ J. NACHTERGAELE ${ }^{1}$, C. KOSMAS $^{3}$, M.J. ROXO ${ }^{4}$, T. DE \\ FIGUEIREDO $^{5}$ \\ ${ }^{1}$ Laboratory for Experimental Geomorphology, KU Leuven, Redingenstraat 16, B-3000 Leuven, Belgium \\ ${ }^{2}$ Fund for Scientific Research - Flanders \\ ${ }^{3}$ Agricultural University of Athens, Greece \\ ${ }^{4}$ Universidade Nova de Lisboa, Portugal \\ ${ }^{5}$ Escola Superior Agraria de Bragana, Apartado 172, P-5300 Bragana, Portugal
}

Received 20 July 1999; Revised 14 March 2000; Accepted 5 April 2000

\begin{abstract}
In Mediterranean areas the dynamics of gully development act as an important indicator of desertification. However, little is known about the influence of climate and land-use changes, and almost no field data exist to assess the sensitivity of a landscape to gully erosion. Two important components of gully erosion studies are the prediction of where gullies begin and where they end. To address some of these issues, topographical thresholds for gully initiation and sedimentation in six different Mediterranean study areas were established. Field measurements of local soil surface slope $(S)$ and drainage-basin area $(A)$ at the point of initiation of ephemeral gullies in intensively cultivated fields (five datasets) and permanent gullies in rangelands (three datasets) were carried out. A negative power relationship of the form $S=a A^{-b}$ was fitted through all datasets, and defined as the mean topographical threshold for gullying in the respective area. Topographically controlled slopes of sedimentation at the gully bottom were also measured. Compared to theoretical relationships for channel initiation by overland flow, relatively low values for $b$ are obtained, suggesting a dominance of overland flow and an influence of subsurface flow. The influence of landsliding at steeper slopes appeared from the flattening of the overall negative trend in the higher slope range $(S>0.30)$ of the integrated dataset. Comparing the threshold lines of our datasets to the average trend lines through data found in literature revealed that vegetation type and cover could better explain differences in topographical thresholds level than climatic conditions. In cultivated fields, soil structure and moisture conditions, as determined by the rainfall distribution, are critical factors influencing topographical thresholds rather than daily rainfall amounts of the gully-initiating events. In rangelands, vegetation cover at the time of incision appears to be the most important factor differentiating between topographical thresholds, overruling the effect of average annual rainfall amounts. Soil texture and rock fragment cover contributed little to the explanation of the relative threshold levels. Differences in regression slopes $(b)$ between the $S-A$ relationships found in this study have been attributed to the soil characteristics in the different study areas, determining the relative importance of subsurface flow and Hortonian overland flow. Sedimentation slopes where both ephemeral and permanent gullies end were generally high because of the high rock fragment content of the transported sediment. A positive relationship was found between the rock fragment content at the apex of the sedimentation fan and the slope of the soil surface at this location. Copyright (C) 2000 John Wiley \& Sons, Ltd.
\end{abstract}

KEY WORDS: gully initiation; sedimentation; climate and land-use impact; topography; soil characteristics

\section{INTRODUCTION}

Throughout Mediterranean Europe gully erosion is a widespread form of soil degradation which is highly sensitive to climate and land-use changes (Poesen and Hooke, 1997). Increased rainfall variability and (over)intensive exploitation of agricultural land are subprocesses of the general desertification trend within the Mediterranean environment, leading to increased rainfall erosivity and soil erodibility (Geeson and Thornes,

\footnotetext{
* Correspondence to: L. Vandekerckhove, Laboratory for Experimental Geomorphology, Catholic University of Leuven, Redingenstraat 16, B-3000 Leuven, Belgium. E-mail: liesbeth.vandekerckhove@geo.kuleuven.ac.be

Contract/grant sponsor: MEDALUS (Mediterranean Desertification and Land Use) collaborative research project, funded by the European Commission Environment and Climate Research Programme; contract/grant number: ENV4-CT95-0118, Climatology and Natural Hazards
}

Copyright (C) 2000 John Wiley \& Sons, Ltd. 


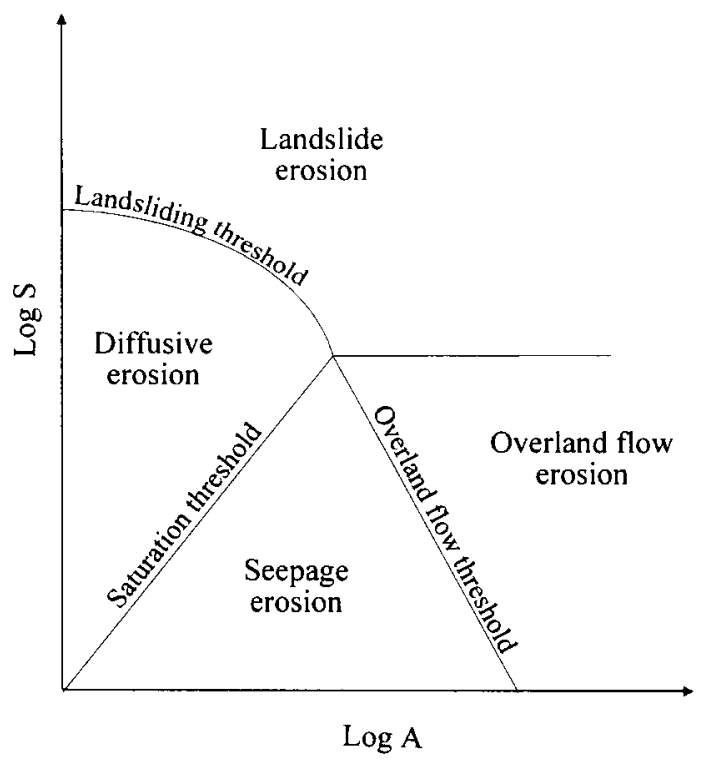

Figure 1. Division of the landscape into process regimes in which different sediment transport and channel initiation mechanisms operate (after Montgomery and Dietrich, 1994). $A=$ drainage-basin area; $S=$ local slope of the soil surface at the gully head

1996). Therefore, the dynamics of gully development in these areas can act as an important indicator of desertification. The prediction of the channel head location is an essential component of theories of channel network growth (Montgomery and Dietrich, 1988). Channel initiation is controlled by a variety of processes which may be modelled as threshold phenomena. Prosser (in press) defined the areas most at risk of gully erosion as those close to process thresholds where climatic change may lead to the onset of landsliding or increase the tendency for Hortonian overland flow. Dietrich et al. (1986, 1992), Montgomery and Dietrich (1994) and Prosser and Abernethy (1996) provided simple analytical models for channel initiation by different processes, involving different relations between contributing drainage area $(A)$ and local slope $(S)$ at the channel head. Thus, the spatial variation in the dominance of different channel initiation and sediment transport mechanisms can be quantitatively defined. Figure 1 (after Montgomery and Dietrich, 1994) shows a theoretical division of the landscape into process regimes in terms of $S$ and $A$. However, the position of individual thresholds may vary with changing climatic and land-use conditions. Comparison of these theoretical relationships with field data for channel head locations in different environments allows prediction of landscape response to climate and land-use changes.

Amongst the first data on $S$ and $A$ at gully heads were those collected by Brice (1966) in Nebraska, USA, and by Patton (1973) in northwestern Colorado. Using these data, Patton and Schumm (1975) found a negative trend between $S$ and $A$, and the lower limit of scatter of the data was proposed as a critical $S-A$ relationship to identify unstable valley floors. The same data were also used by Begin and Schumm (1979) to define a threshold relationship between $S$ and $A$ based on a critical shear stress for incision by overland flow. Montgomery and Dietrich (1988) provided datasets on $S$ and $A$ for gully initiation by shallow landsliding and seepage erosion on steeper slopes, and saturation overland flow on low-gradient slopes, collected in three catchments in western USA. The collection of datasets was extended with $S-A$ data for gully initiation by Hortonian overland flow or by landsliding, and supported analytical process models (Montgomery and Dietrich, 1994). Dietrich et al. (1992) were able to predict the channelled elements of a digital terrain model (DTM) from the Marin County catchment, California, using realistic estimates for the physical parameters in models for ground saturation (O'Loughlin, 1986), landslide instability (Dietrich et al., 1986; Montgomery and Dietrich, 1989) and saturation overland flow. Prosser and Abernethy (1996) identified the model parameters for Hortonian and saturation overland flow using DTM data from a stable gully network in southeastern Australia, and were able to distinguish between the likely processes that control channel 
incision. Such quantitative studies show that the models for overland flow are all very sensitive to critical shear stress, so that small changes in surface resistance by land-use or climate change could lead to important variations in the channel head locations. According to Prosser and Slade (1994), there is a greater potential for climate change to impact gully initiation through changes in resistance to scour than by increases to the magnitude of events. Vandaele et al. (1996) and Poesen et al. (1998a) summarized data on $S$ and $A$ for gully initiation in different environments, but only one dataset was available from a Mediterranean environment (Vandaele et al., 1995). Vandekerckhove et al. (1998) collected two more datasets on topographical thresholds for ephemeral gully initiation in intensively cultivated areas in southeast Spain and northeast Portugal. Up to the present time, these are the only $S-A$ data for the Mediterranean that were obtained entirely by field measurements. Despite the importance of gully erosion and the increasing threat of desertification in this region, no research has been conducted to assess the potential interaction between changing climatic and land-use conditions, and the dynamics of gully development.

The first objective of this study was to collect additional field data on topographical thresholds for gully initiation in different Mediterranean environments. This enabled us to assess the influence of different environmental conditions on the location of gully heads, and hence the sensitivity of a landscape to gully erosion. This also allowed us to establish trends that can be extrapolated to other areas and to predict the effects of potential changes in climate and land use.

In this study, a gully is defined as an ephemeral or permanent channel with a minimum cross-section of $930 \mathrm{~cm}^{2}$ (1 $\mathrm{ft}^{2}$; Poesen et al., 1996). A gully may either start off as a rill or show a clear headcut, but the initiation point is always defined by the conventional minimum cross-section. Ephemeral gullies are temporary erosion features found in cultivated lands, eroded during one or a number of successive runoff events and finally erased by tillage practices. Permanent gullies are found in rangelands which are often abandoned agricultural fields where they are not obliterated by tillage operations after their initiation, and hence result from longer-term runoff erosion activity.

Traditionally, ephemeral gully erosion has been neglected in both empirical erosion models such as the RUSLE (Renard et al., 1994) and in most process-based models, due to the one-sided interest in interrill and rill erosion in the past (Poesen et al., 1996). A few exceptions, including CREAMS (Knisel, 1980) and EGEM (USDA SCS, 1992), do account for gully erosion, but require the knowledge of landscape positions where the initiation of ephemeral gullies is expected, as well as the locations where the gullies end, i.e. sedimentation is likely to occur (Poesen et al., 1998a; Nachtergaele et al., in press). Consequently, the prediction of potential gully head locations resulting from this study is also useful as an input for such erosion models.

The second objective was to inventory the sedimentation slopes of the studied gullies, in order to obtain a range of threshold slopes where gullies are likely to end in each Mediterranean study area.

\section{STUDY AREAS}

Six distinct study areas with ephemeral or permanent gullies were selected throughout the Mediterranean, covering a representative range of lithologies, land-use types and climatic conditions (Figure 2). Two study areas are located in the Guadalentin basin, southeast Spain, i.e. the Rambla Chortal catchment (study area 1) and the Cerro Tonosa in the Rambla Nogalte catchment (study area 2). The third study area is located in the southwestern part of the Sierra de Gata in the Almeria province, southeast Spain. Two study areas were selected in north and south Portugal, i.e. study area 4 around the city of Bragana (east of the Serra da Nogueira) and study area 5 in the Alentejo region (north of Mertola). Study area 6 on Lesvos island, Greece, is located in the western part of the island near the town of Antissa. The Guadalentin basin, the Alentejo and Lesvos island are also target areas within the framework of the European MEDALUS (Mediterranean Desertification and Land Use) project. The main characteristics of the study areas are summarized in Table I.

Most study areas have a semi-arid climate, with a mean annual temperature varying between $16 \cdot 3{ }^{\circ} \mathrm{C}$, and $18.6^{\circ} \mathrm{C}$, and a mean annual precipitation varying between $182 \mathrm{~mm}$ and $490 \mathrm{~mm}$ (Table I). Intense rainfall events, mainly concentrated in spring and autumn but with a great spatial and temporal variability, are typical for a semi-arid climate. High interannual variabilities are also observed. For instance in the Sierra de Gata (study area 3), a minimum of $111 \mathrm{~mm} \mathrm{a}^{-1}$ and maximum of $293 \mathrm{~mm} \mathrm{a}^{-1}$ was measured between 1976 and 

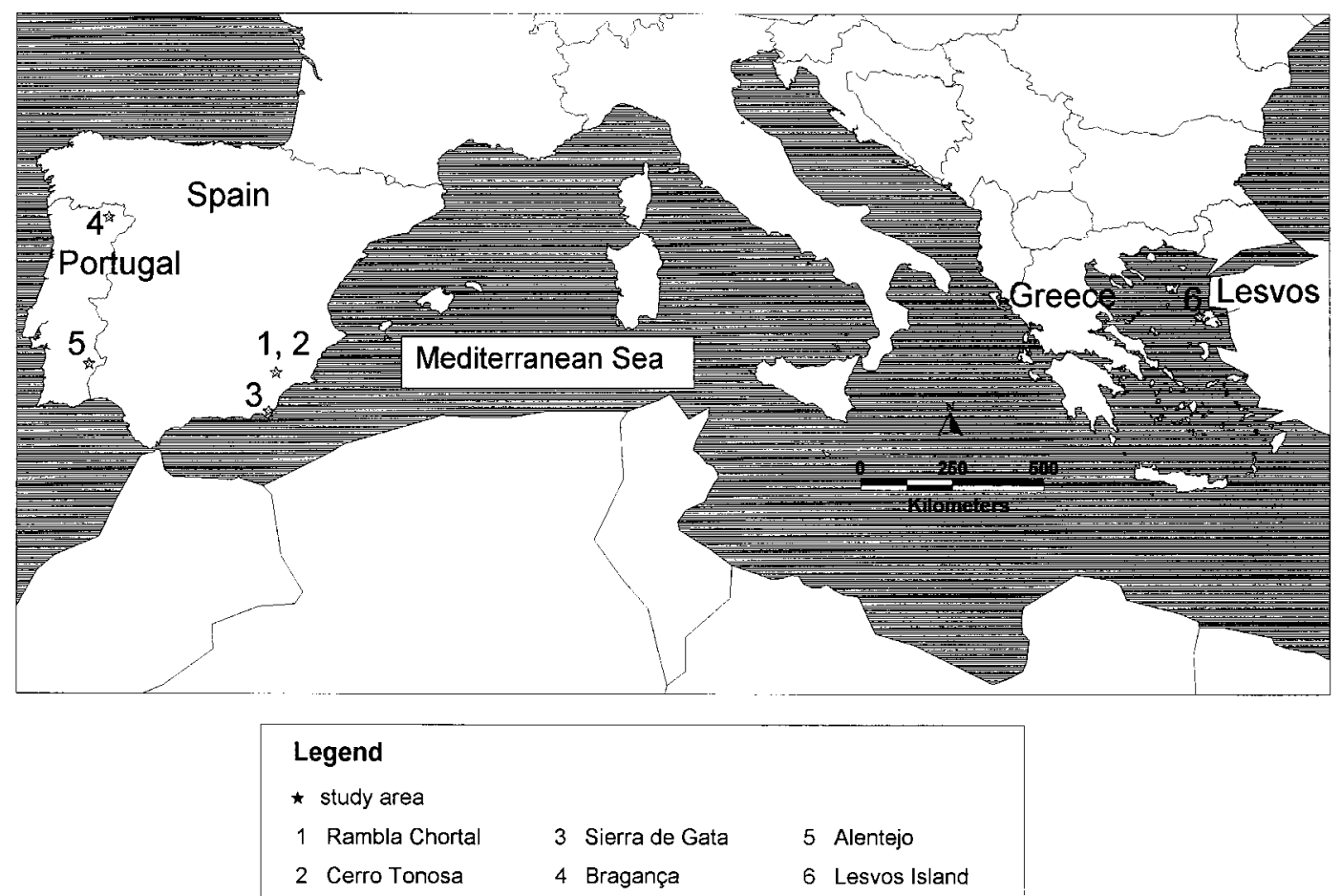

Figure 2. Location of the study areas in the Mediterranean

1992 (Berael, 1994). Bull et al. (1999) illustrated variations in rainfall intensities within the Nogalte catchment, including study area 2 . Study area 4 has a subhumid climate which is characterized by a mean annual temperature of $12.0{ }^{\circ} \mathrm{C}$, a mean annual precipitation of $740 \mathrm{~mm}$ and a more even rainfall distribution of mainly frontal winter rains.

Various land-use types were observed in the different study areas. The land use represented in the studied gully catchments is given in Table I. In the Rambla Chortal catchment (study area 1) and in the Cerro Tonosa area (study area 2), the gullied fields were used for almond cultivation which is the main land use in the area. The almond groves are ploughed three to five times a year to control weeds and to conserve soil water (Poesen et al., 1997). The studied hillslopes in the Sierra de Gata (study area 3) are presently used for sheep and goat grazing, although the lower slopes used to be cultivated for wheat production. Most of wheat fields were abandoned at least 40 years ago, but some slopes were still cultivated until 10 to 20 years ago. Since abandonment, a thin plant cover with Anthyllis cytisoides, Chamaerops humilis, Euphorbia spinosa L., Aspagarus stipularis and Thymelaea hirsuta has colonized the land. The upper parts of the hillslopes were never cultivated and are mainly covered by Stipa tenacissima (Poesen et al., 1998b; Oostwoud Wijdenes et al., 1999). In study area 4 around Bragana, winter wheat or rye was cultivated in the studied gully catchments and represent important crops for the area. The main land use in the Alentejo (study area 5) consists of a rotation where (autumn-sown) winter wheat and barley production alternates with several years of fallow. The fallow land is covered by grass, interspersed by colonizing Cystus plants, and is used for grazing by sheep and goats. Both the cultivated and the fallow land were included in the study. Study area 6 on Lesvos is covered by maquis vegetation used for grazing and consisting mainly of needle leaf shrubs (Sarcopoterium spinosum) and annual grasses and herbs. The grazing intensity is 1.8 animals per hectare, but overgrazing and burning of the shrubs every two to three years are common.

Soil types (FAO, 1994) and associated parent materials found in the studied gully catchments are listed in Table I. Leptosols occurred in all study areas and Regosols are the second most represented soil type. 
Table I. Main characteristics of the study areas

\begin{tabular}{|c|c|c|c|c|c|c|c|}
\hline Study area & $\begin{array}{l}\text { Mean altitude } \\
(\mathrm{m} \text { a.s.l.) }\end{array}$ & Land use & Parent material & Soil type (FAO, 1994) & $\begin{array}{c}P_{\text {annual }} \\
(\mathrm{mm})\end{array}$ & $T_{\text {annual }}\left(\mathrm{C}^{\circ}\right)$ & $\begin{array}{l}\text { Climatic } \\
\text { type }\end{array}$ \\
\hline $\begin{array}{l}\text { 1. Rambla Chortal, } \\
\text { Guadalentin, SE Spain }\end{array}$ & 600 & Almond groves & Shales and greywackes & $\begin{array}{l}\text { Lithic and Eutric Leptosols, } \\
\text { Eutric Regosols }\end{array}$ & $\begin{array}{l}280^{\mathrm{b}} \\
(345)\end{array}$ & $17 \cdot 5^{\mathrm{b}}$ & Semi-arid \\
\hline $\begin{array}{l}\text { 2. Cerro Tonosa, } \\
\text { Guadalentin, SE Spain }\end{array}$ & 1100 & Almond groves & Phyllites and quartzites & $\begin{array}{l}\text { Lithic and Eutric Leptosols, } \\
\text { Eutric Regosols }\end{array}$ & $\begin{array}{l}280^{\mathrm{b}} \\
(425)\end{array}$ & $17 \cdot 5^{\mathrm{b}}$ & Semi-arid \\
\hline $\begin{array}{l}\text { 3. Sierra de Gata, } \\
\text { Almeria, SE Spain }\end{array}$ & 120 & Rangeland $^{\mathrm{a}}$ & $\begin{array}{l}\text { Andesitic rocks, alluvial } \\
\text { fan deposits }\end{array}$ & $\begin{array}{l}\text { Lithic and Eutric Leptosols, Calcaric } \\
\text { Cambisols, Haplic and Petric Calcisols }\end{array}$ & $182^{\mathrm{c}}$ & $18 \cdot 6^{\mathrm{g}}$ & Semi-arid \\
\hline $\begin{array}{l}\text { 4. Bragana, } \\
\text { N Portugal }\end{array}$ & 900 & Cereal crops & $\begin{array}{l}\text { Schists, granites, quartzites } \\
\text { (ultra)mafic rocks, colluvial } \\
\text { deposits }\end{array}$ & $\begin{array}{l}\text { Eutric Leptosols, Chromic Luvisols, } \\
\text { Eutric Cambisols, Eutric Regosols }\end{array}$ & $740^{\mathrm{d}}$ & $12 \cdot 0^{\mathrm{d}}$ & Subhumid \\
\hline $\begin{array}{l}\text { 5. Alentejo, } \\
\text { S Portugal }\end{array}$ & 150 & $\begin{array}{l}\text { Cereal crops/ } \\
\text { rangeland }^{\mathrm{a}}\end{array}$ & $\begin{array}{l}\text { Micashists, colluvial } \\
\text { deposits }\end{array}$ & $\begin{array}{l}\text { Eutric Leptosols, Chromic Luvisols, } \\
\text { Chromic Cambisols, Eutric Regosols }\end{array}$ & $490^{\mathrm{e}}$ & $16 \cdot 3^{\mathrm{h}}$ & Semi-arid \\
\hline 6. Lesvos island, & 260 & Rangeland & Volcanic rocks & Eutric Leptosols, Eutric Regosols & $405^{\mathrm{f}}$ & $17 \cdot 7^{\mathrm{f}}$ & Semi-arid \\
\hline \multicolumn{8}{|c|}{$\begin{array}{l}\text { a Abandoned agricultural land } \\
\text { b Average of values measured at the Puentes reservoir ( } 450 \mathrm{~m} \text { a.s.l.) and in Puerto Lumbreras ( } 460 \mathrm{~m} \text { a.s.l.) from Andrade (1990); pr } \\
\text { estimated by Boer (1999), based on the altitude of the study areas } \\
\text { c Measured between } 1976 \text { and } 1992 \text { at the research station of Michelin, located in the study area (Berael, 1994) } \\
\text { d Measured between } 1984 \text { and } 1995 \text { in Bragana (de Figueiredo, personal communication) } \\
\text { e Calculated from seven rain gauges near the study area over a } 30 \text { year period (1957-1986) (Roxo, personal communication) } \\
\text { f Measured in the study area (Kosmas, personal communication) } \\
\text { g Measured at the Cabo de Gata (Walter and Lieth, 1960) } \\
\text { h Measured at Mertola over a } 30 \text { year period (1957-1986) (Climatic Research Unit, University of East Anglia, 1999) }\end{array}$} \\
\hline
\end{tabular}


Leptosols are limited in depth by the presence of a continuous hard layer within $30 \mathrm{~cm}$ of the surface, such as a fragmented bedrock in the Guadalentin, or a petrocalcic horizon in the Sierra de Gata. Typical for Regosols is a poorly developed AC profile. Generally, the A horizon of both soil types showed a high rock fragment content or cover. Cambisols and Luvisols occurred in both Portuguese study areas (4 and 5). In study area 3 in the Sierra de Gata, Cambisols and locally Calcisols were also found.

\section{MATERIALS AND METHODS}

In each study area, topographical, soil and vegetation parameters were collected for a selection of ephemeral gullies in cultivated fields or permanent gullies in rangelands. Local slope of the soil surface $\left(S, \mathrm{~m} \mathrm{~m}^{-1}\right)$ was measured at the gully initiation point with a clinometer and the drainage-basin area $(A$, ha) was delimited by visual assessment of local topography and signs of overland flow. The area was subdivided into smaller polygons (quadrangles and triangles) which were measured with a measuring tape. The total drainage-basin area was then calculated as the sum of the areas of the individual polygons. For some datasets a differential GPS was used to measure the drainage-basin area. Soil texture data, including clay, silt and sand content, were obtained from soil samples taken at the gully heads. The samples were analysed using the sieve-pipette method upon addition of a dispersing agent, and the USDA soil texture class was derived. Rock fragment content by mass was determined from a limited number of samples, or was estimated visually in the field. Rock fragment cover of the soil surface near the gully head was determined by visual estimation or by the point-count method. Slides taken from the surface were projected on a raster plot with 140 grid points on which the rock fragments were counted (Oostwoud Wijdenes et al., 1999; Poesen et al., 1997). Vegetation cover in rangeland catchments was visually estimated.

Table II. Rainfall characteristics of the events responsible for the formation of ephemeral gullies in cultivated lands

\begin{tabular}{|c|c|c|c|c|c|}
\hline Dataset & $\begin{array}{l}\text { Period of data } \\
\text { collection }\end{array}$ & ${ }_{(\mathrm{mm})^{1}}^{P_{\text {before }}{ }^{1}}$ & $P_{\text {gully }}^{2}$ & $\begin{array}{l}P_{\text {after }}^{3} \\
(\mathrm{~mm})\end{array}$ & $\begin{array}{l}P_{\mathrm{tot}}^{4} \\
(\mathrm{~mm})\end{array}$ \\
\hline 1. Rambla Chortal, 1996 & $5 / 3-7 / 3 / 96$ & $\begin{array}{c}\mathbf{9 0 \cdot 5}(1 / 6-31 / 8 / 95)^{\mathrm{a}} \\
\mathbf{5 2 \cdot 2}(1 / 6-22 / 9 / 95)^{\mathrm{b}} \\
\mathbf{4 5 \cdot 5}(1 / 6-1 / 9 / 95)^{\mathrm{c}}\end{array}$ & $\begin{array}{l}14 \cdot 5(1 / 9 / 95)^{\mathrm{a}} \\
9 \cdot 7(23 / 9 / 95)^{\mathrm{b}} \\
\mathbf{7 \cdot 5}(2 / 9 / 95)^{\mathrm{c}}\end{array}$ & $\begin{array}{c}100 \cdot 5(2 / 9 / 95-4 / 3 / 96)^{\mathrm{a}} \\
93 \cdot 7(24 / 9 / 95-4 / 3 / 96)^{\mathrm{b}} \\
101(3 / 9 / 95-4 / 3 / 96)^{\mathrm{c}}\end{array}$ & $\begin{array}{r}205 \cdot 5^{\mathrm{a}} \\
155 \cdot 6^{\mathrm{b}} \\
154^{\mathrm{c}}\end{array}$ \\
\hline 2. Bragana, 1996 & $17 / 3-21 / 3 / 96$ & $\mathbf{5 0 5 . 9}(1 / 11 / 95-6 / 1 / 96)^{\mathrm{d}}$ & $61(7 / 1 / 96)^{\mathrm{d}}$ & $315 \cdot 4(8 / 1-16 / 3 / 96)$ & $882 \cdot 3$ \\
\hline 3. Cerro Tonosa, 1996 & $26 / 11-1 / 12 / 96$ & $\begin{array}{c}46(1 / 6-10 / 9 / 96)^{\mathrm{a}} \\
\mathbf{2 5 \cdot 8}(1 / 6-10 / 9 / 96)^{\mathrm{b}} \\
\mathbf{8}(1 / 6-8 / 9 / 96)^{\mathrm{c}}\end{array}$ & $\begin{array}{c}\mathbf{2 6}(11 / 9 / 96)^{\mathrm{a}} \\
\mathbf{2 1 \cdot 5}(11 / 9 / 96)^{\mathrm{b}} \\
\mathbf{3 1 \cdot 5}(9 / 9 / 96)^{\mathrm{c}}\end{array}$ & $\begin{array}{c}\mathbf{5 7 - 5}(12 / 9-25 / 11 / 96)^{\mathrm{a}} \\
\mathbf{3 9 \cdot 7}(12 / 9-25 / 11 / 96)^{\mathrm{b}} \\
\mathbf{8 0}(10 / 9-25 / 11 / 96)^{\mathrm{c}}\end{array}$ & $\begin{array}{l}129 \cdot 5^{\mathrm{a}} \\
87^{\mathrm{b}} \\
119 \cdot 5^{\mathrm{c}}\end{array}$ \\
\hline 4. Rambla Chortal, 1998 & $11 / 1-17 / 1 / 98$ & $\begin{array}{c}133 \cdot 6(1 / 6-29 / 9 / 97)^{\mathrm{e}} \\
\mathbf{7 8 \cdot 3}(1 / 6-28 / 9 / 97)^{\mathrm{a}} \\
\mathbf{9 2 \cdot 3}(1 / 6-28 / 9 / 97)^{\mathrm{b}} \\
\mathbf{1 3 3 \cdot 5}(1 / 6-28 / 9 / 97)^{\mathrm{c}}\end{array}$ & $\begin{array}{c}49(30 / 9 / 97)^{\mathrm{e}} \\
\mathbf{4 2 \cdot 7}(29 / 9 / 97)^{\mathrm{a}} \\
\mathbf{2 8} \cdot \mathbf{2}(29 / 9 / 95)^{\mathrm{b}} \\
\mathbf{5 2}(29 / 9 / 97)^{\mathrm{c}}\end{array}$ & $\begin{array}{c}\text { n.a. till } 10 / 1 / 98 \\
\mathbf{1 0 5} \cdot \mathbf{4}(30 / 1-10 / 1 / 98)^{\mathrm{a}} \\
\text { n.a. till } 10 / 1 / 98 \\
\text { n.a. till } 10 / 1 / 98\end{array}$ & $\begin{array}{l}\text { n.a. } \\
\mathbf{2 2 6 \cdot 4 ^ { \mathrm { a } }} \\
\text { n.a. } \\
\text { n.a. }\end{array}$ \\
\hline 5. Alentejo, 1998 & $28 / 2-6 / 3 / 98$ & $66 \cdot 2(1 / 11-5 / 11 / 97)^{\mathrm{f}}$ & $74(6 / 11 / 97)^{f}$ & $273 \cdot 2(7 / 11 / 97-27 / 2 / 98)^{\mathrm{f}}$ & $413 \cdot 4^{\mathrm{f}}$ \\
\hline
\end{tabular}

${ }^{1}$ Cumulative rainfall amount between the date of the last tillage operation and the date of the most probable erosion event

${ }_{3}^{2}$ Most probable rainfall event responsible for the initiation of the ephemeral gullies

${ }_{4}^{3}$ Cumulative rainfall amount between the date of the most probable rainfall event and the first day of the field data collection period

${ }^{4}$ Cumulative rainfall amount between the date of the last tillage operation and the first day of the field data collection period $\left(P_{\text {tot }}=P_{\text {before }}+P_{\text {gully }}+P_{\text {after }}\right)$

${ }^{a}$ Measured at Zarcilla de Ramos (Casa Forestal)

$\mathrm{b}$ Measured at the Puentes reservoir (Instituto Nacional de Meteorologia)

${ }^{c}$ Measured at the Vald'Infierno reservoir (Instituto Nacional de Meteorologia)

${ }^{\mathrm{d}}$ Measured in Bragana (de Figueiredo, personal communication)

e Measured in the Rambla Chortal catchment (Hawkes, personal communication)

${ }^{\mathrm{f}}$ Measured in Neves Corvo, Alentejo (Roxo, personal communication)

n.a., not available 
The analysis of these data was based upon the relationship $S=a A^{-b}$, derived by Vandaele et al. (1996) from the 'shear stress indicator' of Begin and Schumm (1979). This relationship was determined for the individual datasets by orthogonal regression (Jackson, 1991) on a double logarithmic scale (Vandekerckhove et al., 1998. This line represents the mean topographical threshold conditions of the sampled gullies and was used for comparison between the study areas. Differences in intercept and slope of the regression lines were statistically tested between the datasets in cultivated lands and between the datasets in rangelands. The effect of vegetation and rock fragment cover at the gully sites on the position and significance of the threshold line was tested. In Lesvos, a distinction was made between sites where hydraulic erosion or where mass movement was the dominant gully-initiating process. Sharp headcuts and the presence of the original catchment vegetation inside the gully bed indicated clearly that the entire topsoil layer had been removed by slope failure and rotational sliding. The entire Lesvos dataset was subdivided according to this process dominance to test its effect on the $S-A$ relationship.

Daily rainfall data were available from one or more stations within or at variable distance from study areas with ephemeral gullies in cultivated lands. Table II presents the relevant data in a comparable way in order to assess and compare threshold conditions between different areas. Because the fields were visited after the ephemeral gullies had been formed, only an approximate date of the erosive events is known from information provided by local people. From the available rainfall records, the maximum daily rainfall amount occurring in a period of two months before and after this date was considered as the most probable event of gully initiation $\left(P_{\text {gully }}\right)$. In most cases, the date of this event agrees well with the approximate date of the erosion event. Antecedent topsoil conditions were assessed by the cumulative rainfall amount recorded between the approximate date of the last tillage operation and the presumable date of the erosion event $\left(P_{\text {before }}\right)$. Any rainfall after this event may have deepened or extended the gullies until the first day of field measurements, and therefore the cumulative rainfall amount in this period was also given $\left(P_{\text {after }}\right)$. If rainfall data for a given study area were provided by more than one station, the spatial variation and hence reliability of the data were assessed by comparing cumulative rainfall amounts as well as the date and rainfall amount of the likely erosion event. In the Guadalentin basin (datasets 1, 3 and 4), daily rainfall data were obtained from the official meteorological stations at Zarcilla de Ramos (Casa Forestal), the Embalse de Puentes and the Embalse de Vald'Infierno. Zarcilla de Ramos is a village located at a distance of $17 \mathrm{~km}$ from the Rambla Chortal (datasets 1 and 4), and $32 \mathrm{~km}$ from the Cerro Tonosa (dataset 3). The Puentes reservoir is located at 9 $\mathrm{km}$ from the Rambla Chortal and at $26 \mathrm{~km}$ from the Cerro Tonosa. The Vald'Infierno reservoir is located at 13 $\mathrm{km}$ from the Rambla Chortal, and at $24 \mathrm{~km}$ from the Cerro Tonosa. In addition, local measurements in the Rambla Chortal (Hawkes, personal communication) were available for dataset 4 .

For permanent gullies in rangelands (abandoned fields), average annual rainfall amounts (Table I) are considered in the interpretation of the topographical threshold conditions for gully initiation instead of individual rainfall events. Detailed rainfall records were not available for these datasets, and moreover, it is not precisely known when the fields have been abandoned and the gullies have been initiated.

For each dataset the slopes of the soil surface where gullies ended due to sedimentation were measured. Sedimentation of the selected gullies was triggered by a decrease in local slope of the soil surface. Cases where sedimentation was induced by a bank or a sudden increase in vegetation cover were not included in the dataset. Frequency distributions of the slopes were constructed in order to compare the different study areas. For the gullies in the Rambla Chortal (dataset 4) and in the Alentejo (datasets 5 and 8), the rock fragment cover at the apex of the sedimentation fan was also determined using the point-count method. This parameter was then related to the slope angle of the sedimentation fan.

\section{RESULTS}

Eight field datasets were collected in six different study areas: five datasets in intensively cultivated fields, and three datasets in rangelands. Figure 3 shows an integrated plot of all collected datasets together with trend lines taken from literature. A trend line was hand-fitted through the integrated dataset from Montgomery and Dietrich (1994) for various landscapes in which both overland flow and landsliding control channel initiation. Two other lines were fitted for the Humboldt range, Nevada, and for the Stanford hills, California, in which 


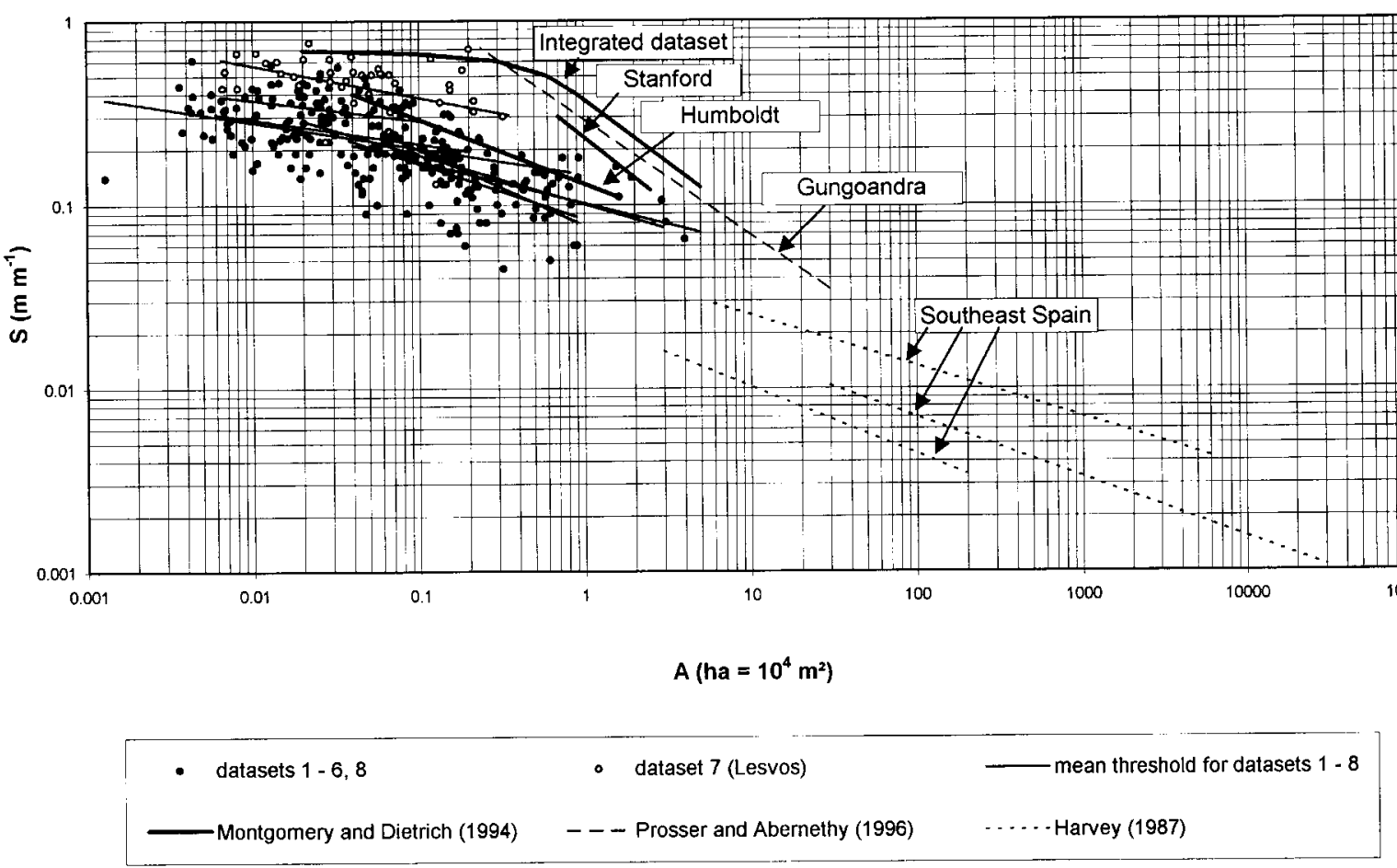

Figure 3. Comparison of the collected datasets with $S-A$ relationships from literature on topographical thresholds for channel initiation in a variety of environments. $A=$ drainage-basin area; $S=$ local slope of the soil surface at the channel head

overland flow is dominant (Montgomery and Dietrich, 1994). A threshold line for channel heads initiated by overland flow in the Gungoandra catchment, Australia, was taken from Prosser and Abernethy (1996). Plots from Harvey (1987) were also added, showing empirical relationships between drainage area and fanhead channel slopes for headcut development and trenching of alluvial fans in southeast Spain.

A negative power relationship between $S$ and $A$ was fitted through all datasets, resulting in different values for the regression parameters $a$ and $b$ of the equation $S=a A^{-b}$. The datasets and mean threshold lines for ephemeral gullies in cultivated lands are plotted together in Figure 4, and for permanent gullies in rangelands in Figure 5. The coefficients $a$ and $b$, the correlation coefficient $\left(R_{c}\right)$, significance level $(P)$ and number of observations $(N)$ for all datasets are given in Table III. Between the datasets in cultivated fields, there was no significant difference in slope of the regression lines at $\alpha=10$ per cent. Significant differences in intercept were found between dataset 3 in the Cerro Tonosa and all other datasets in cultivated fields $(1,2,4$ and 5) at $\alpha=0.1$ or 0.5 per cent, between dataset 1 and 2 at $\alpha=5$ per cent, and between dataset 1 and 5 at $\alpha=5$ per cent. Within the datasets in rangelands, dataset 7 in Lesvos had a significantly lower regression slope than dataset 8 in the Alentejo at $\alpha=10$ per cent, and a significantly higher intercept than both datasets 6 and 8 at $\alpha=0.1$ per cent. Further statistical comparison revealed no significant differences at $\alpha=10$ per cent.

Table IV summarizes the soil and vegetation characteristics of the gully sites derived from the soil samples or other estimation methods. To illustrate the effect of vegetation cover in the catchment on the topographical threshold level, examples are given for Lesvos (hydraulic erosion sites only) and the Sierra de Gata (Figure 6a and $6 \mathrm{~b}$ ). In the Lesvos plot, datapoints with a higher vegetation cover appear in the upper part of the datacloud, whereas in the Sierra de Gata, this trend is less clear. Figure 7 shows the differentiation of the $S-A$ relationships between hydraulic erosion and mass movement dominance for the Lesvos dataset.

Comparison of the different rainfall data for each Spanish dataset (Table II) shows a reasonable correlation between the different data sources. Note that for dataset 4, the measurement of $P_{\text {gully }}$ 'on the spot' is very close to that at the Vald'Infierno reservoir and (to a lesser extent) to that in Zarcilla de Ramos. These findings, 


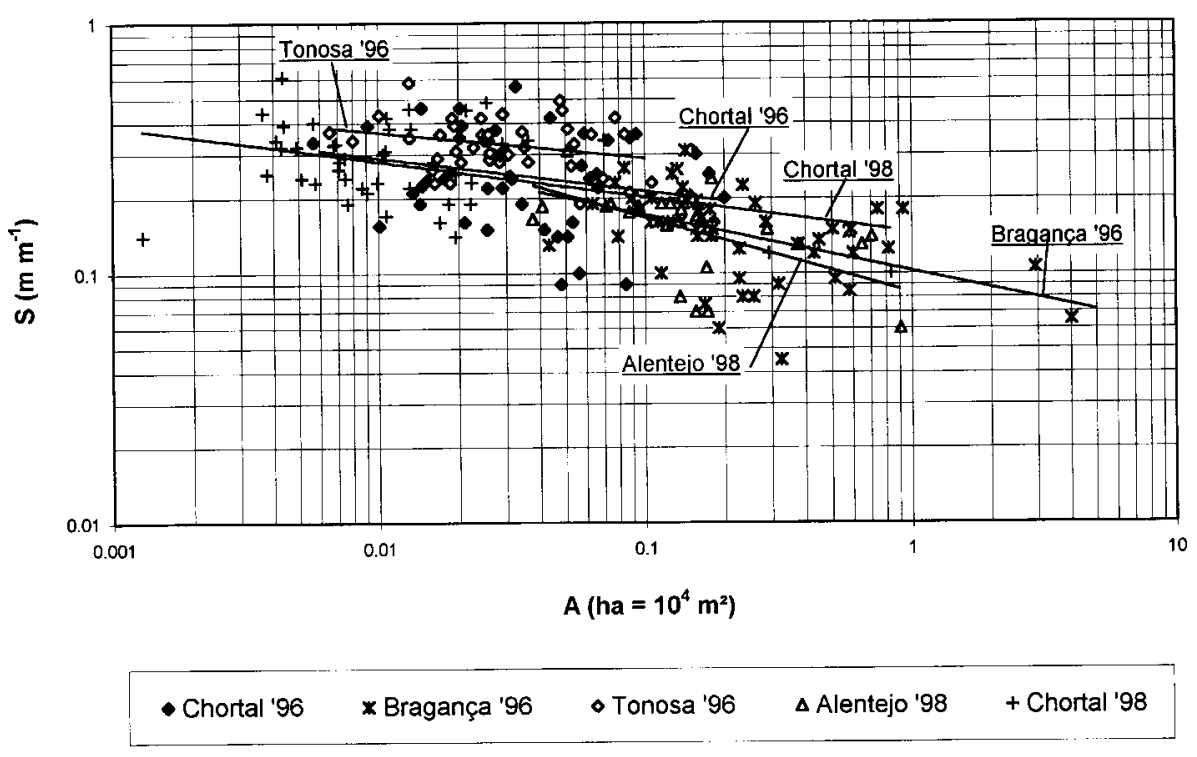

Figure 4. Comparison of the mean topographical threshold conditions $\left(S=a A^{-b}\right)$ for ephemeral gullying in intensively cultivated areas of the Mediterranean. $A=$ drainage-basin area; $S=$ local slope of the soil surface at the gully head

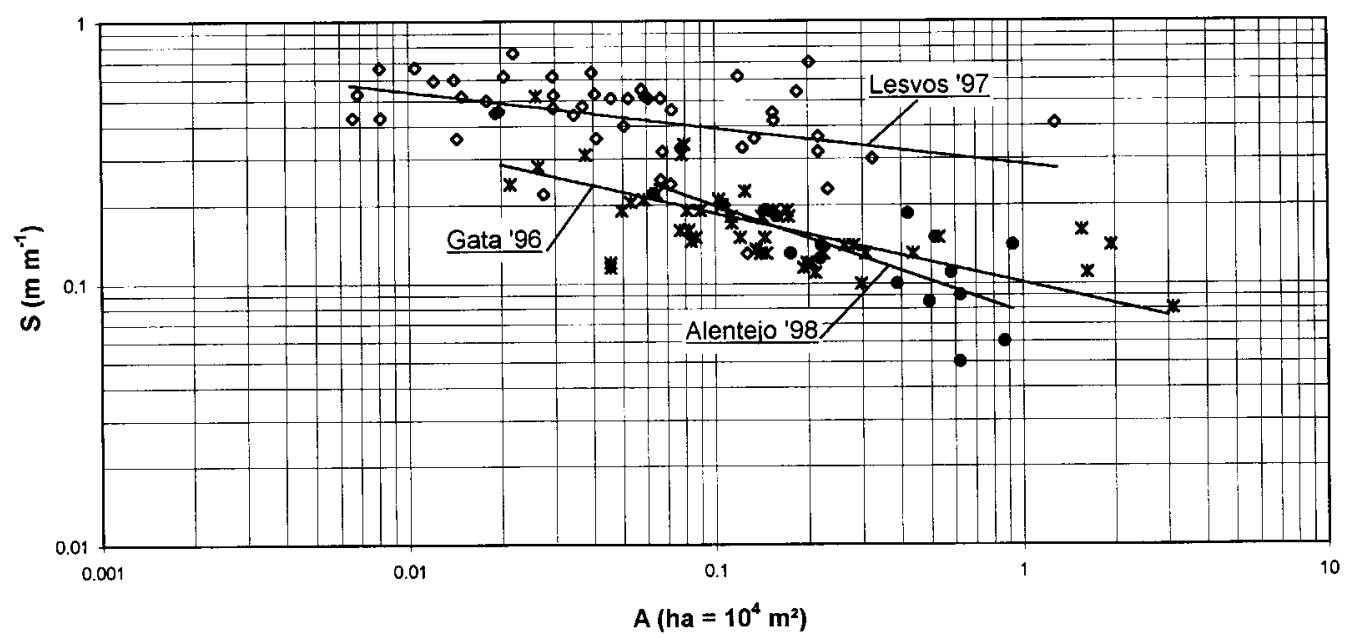

- Lesvos '97 $\quad$ * Gata' '96 Alentejo ' 98

Figure 5. Comparison of the mean topographical threshold conditions $\left(S=a A^{-b}\right)$ for gullying in rangelands of the Mediterranean. $A=$ drainage-basin area; $S=$ local slope of the soil surface at the gully head

in spite of the well known spatial rainfall variability in the Guadalentin, support the use of the data from the three official stations at some distance from the Rambla Chortal and the Cerro Tonosa to characterize at least relative differences between the rainfall events in these study areas.

Diagrams showing the frequency distributions of slope gradients where the gullies end in a fan (by topographically induced sedimentation) for the different study areas are shown in Figure 8 (cultivated lands) and Figure 9 (rangelands). The relationships between the rock fragment cover at the apex of the sedimentation 
Table III. Regression coefficients $a$ and $b$ of the equation $S=a A^{-b}\left(S\right.$ in m m$~_{-1}, A$ in ha) correlation coefficient $\left(R_{c}\right)$, significance level $(P)$ and number of observations $(N)$ of the datasets collected in cultivated fields (1 to 5), plotted in Figure 3, and the datasets collected in rangelands (6 to 8), plotted in Figure 4

\begin{tabular}{|c|c|c|c|c|c|}
\hline Dataset & $a$ & $b$ & $R_{\mathrm{c}}$ & $P$ & $N$ \\
\hline 1. Rambla Chortal, 1996 & $0 \cdot 157$ & $0 \cdot 133$ & $-0 \cdot 210$ & $0 \cdot 144$ & 50 \\
\hline 2. Bragana, 1996 & $0 \cdot 102$ & $0 \cdot 226$ & -0.424 & 0.002 & 50 \\
\hline 3. Cerro Tonosa, 1996 & 0.227 & $0 \cdot 104$ & $-0 \cdot 251$ & $0 \cdot 118$ & 40 \\
\hline 4. Rambla Chortal, 1998 & $0 \cdot 146$ & $0 \cdot 142$ & $-0 \cdot 385$ & $0 \cdot 008$ & 37 \\
\hline 5. Alentejo, 1998 & 0.083 & $0 \cdot 303$ & $-0 \cdot 514$ & $0 \cdot 010$ & 24 \\
\hline 6. Sierra de Gata, 1996 & $0 \cdot 101$ & $0 \cdot 267$ & -0.663 & $<0.001$ & 52 \\
\hline 7. Lesvos, 1997 & $0 \cdot 285$ & $0 \cdot 139$ & $-0 \cdot 400$ & 0.004 & 50 \\
\hline 8. Alentejo, 1998 & 0.077 & 0.414 & -0.719 & 0.002 & 16 \\
\hline
\end{tabular}

Table IV. Site parameters at the gully heads in the different study areas

\begin{tabular}{|c|c|c|c|c|c|c|c|}
\hline \multirow{2}{*}{$\begin{array}{l}\text { Study area } \\
\text { Cover }^{1}(\%)\end{array}$} & \multirow{2}{*}{$\begin{array}{l}\text { Vegetation } \\
\text { Content }^{2}(\%)\end{array}$} & \multicolumn{2}{|c|}{ Rock fragment } & \multicolumn{4}{|c|}{ Soil texture ${ }^{4}$} \\
\hline & & Cover $^{3}(\%)$ & Clay (\%) & $\begin{array}{l}\text { Silt } \\
(\%)\end{array}$ & $\begin{array}{l}\text { Sand } \\
(\%)\end{array}$ & & Classification (USDA) \\
\hline 1. Rambla Chortal & - & $\begin{array}{c}50(20-66)^{*} \\
n=46\end{array}$ & $\begin{array}{c}93(52-100)^{*} \\
n=46\end{array}$ & 12 & 29 & 59 & $\begin{array}{l}\text { Sandy loam } \\
n=46\end{array}$ \\
\hline 2. Cerro Tonosa & - & $\begin{array}{c}50(20-66)^{*} \\
n=46\end{array}$ & $\begin{array}{c}93(52-100)^{*} \\
n=46\end{array}$ & 12 & 29 & 59 & $\begin{array}{l}\text { Sandy loam } \\
n=46\end{array}$ \\
\hline 3. Sierra de Gata & $\begin{array}{c}18(5-70) \\
n=49\end{array}$ & n.a. & $\begin{array}{c}56(24-85)^{*} \\
n=52\end{array}$ & 25 & 69 & 6 & $\begin{array}{l}\text { Silt loam } \\
n=23\end{array}$ \\
\hline 4. Bragana & - & $\begin{array}{c}6(1-15)^{* *} \\
n=50\end{array}$ & $\begin{array}{c}15(2-30)^{* * *} \\
n=50\end{array}$ & 12 & 24 & 64 & $\begin{array}{l}\text { Sandy loam } \\
n=26\end{array}$ \\
\hline 5. Alentejo & $\begin{array}{c}68(30-90) \\
n=16\end{array}$ & $\begin{array}{c}29(14-61)^{*} \\
n=40\end{array}$ & $\begin{array}{c}58(20-93)^{*} \\
n=39\end{array}$ & 13 & 34 & 53 & $\begin{array}{c}\text { Sandy loam -loam } \\
n=40\end{array}$ \\
\hline 6. Lesvos island & $\begin{array}{c}75(30-100) \\
n=49\end{array}$ & $\begin{array}{c}13(2-24)^{*} \\
n=11\end{array}$ & $\begin{array}{c}20(5-85)^{* *} \\
n=50\end{array}$ & 18 & 29 & 53 & $\begin{array}{c}\text { Sandy loam -loam } \\
n=11\end{array}$ \\
\hline
\end{tabular}

\footnotetext{
${ }^{1}$ Visually estimated in the gully catchment, only for rangelands: average value and (minimum-maximum)

${ }^{2}$ Determined by mass from soil samples taken at the gully head ${ }^{*}$ or visually estimated ${ }^{* *}$ : average value and (minimum-maximum)

${ }^{3}$ Determined by the point-count method ${ }^{*}$ or visually estimated ${ }^{* *}$ : average value and (minimum-maximum)

${ }^{4}$ Determined by the sieve-pipette method with addition of a dispersing agent: average values (for Brangaa: Agroconsultores e Coba (1991) Carta dos Solos do Nordeste de Portugal: Memórias. UTAD, Vila Real)
}

fan and the sedimentation slope for the gullies in the Rambla Chortal and in the Alentejo are shown in Figure 10.

\section{DISCUSSION}

\section{S-A Relationships and threshold levels: theories and data}

Integrating all datasets (Figure 3 ) results in a widely scattered data cluster in which an overall negative trend can be discerned. Compared to theoretical $S-A$ relationships, the relatively weak regression slopes of the individual datasets (Table III) suggest a dominance of overland flow with an influence of subsurface flow. Montgomery and Dietrich (1994) proposed negative $S-A$ relationships for gully initiation by turbulent $(b=0 \cdot 86)$ and laminar $(b=0.5)$ Hortonian overland flow (Figure 1). The index A.S expressing erosivity of overland flow (Moore et al., 1988) also implies a negative relationship between $S$ and $A$ but with equal importance of the parameters $(b=1)$. Subsurface processes involve a positive relationship between $A$ and $S$, as shown by Montgomery and Dietrich (1994, Figure 1) and expressed by the wetness index $\ln (A / S)$ (Moore et al., 1988). Consequently, the influence of subsurface flow weakens the negative trend implied by Hortonian overland flow and may be underlying the trends obtained from our empirical datasets. In all study 

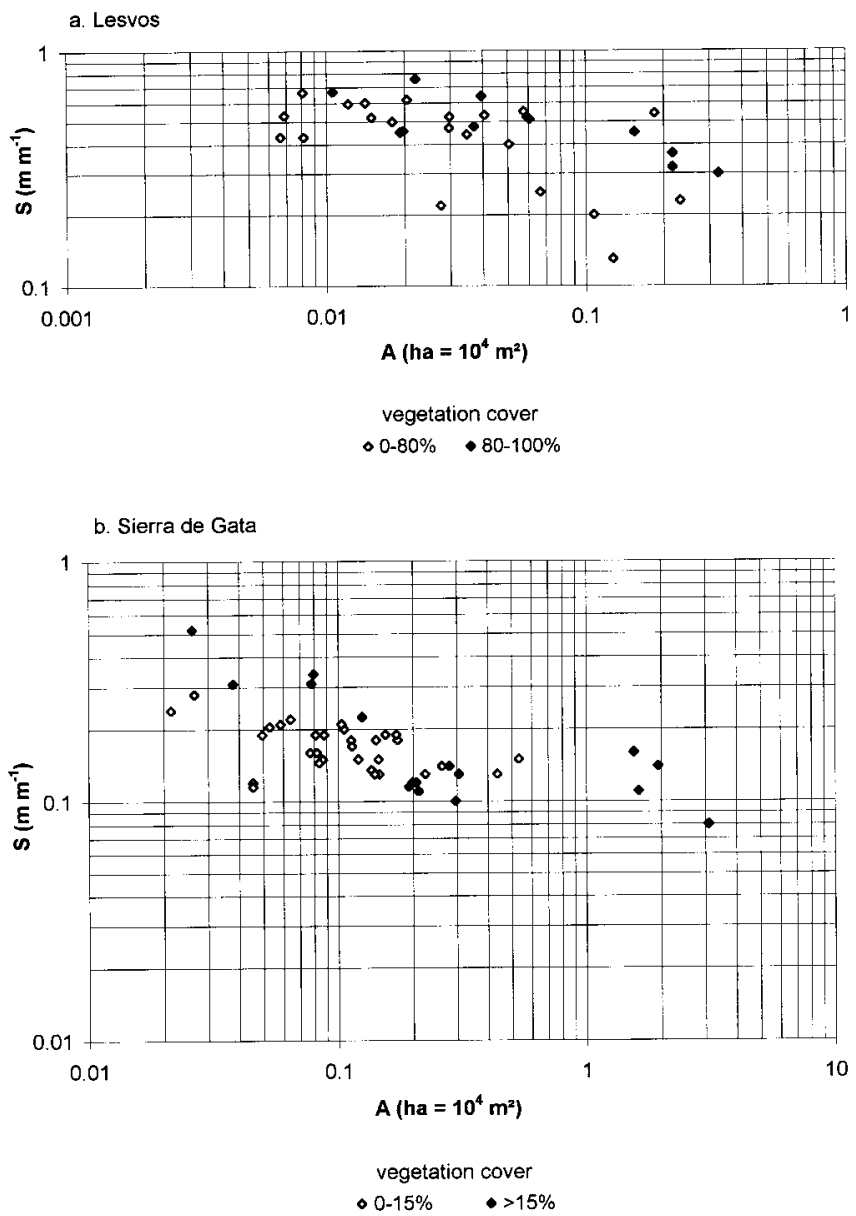

Figure 6 . The effect of catchment vegetation cover on the topographical threshold level for the initiation of gullies by hydraulic erosion in (a) Lesvos and (b) the Sierra de Gata

areas, soil properties facilitating subsurface flow were found, such as a large rock fragment content and cover of the topsoil, and the presence of an impermeable layer (bedrock, $B_{t}$ horizon, petrocalcic horizon) at shallow depth. It can also be seen in Figure 3 that the datasets for channel initiation by Hortonian overland flow in the Humboldt Range, Nevada, and in the Stanford hills, California (Montgomery and Dietrich, 1994), in Gungoandra Creek, Australia (Prosser and Abernethy, 1996), and in southeast spain (Harvey, 1987), have steeper slopes than the individual trends in our datasets. Moreover, the negative trend in the integrated dataset (Figure 3 ) is more pronounced in the lower slope range and tends to flatten out in the higher slope range where drainage-basin areas decrease more rapidly with slope. According to the models of Montgomery and Dietrich (1994), the process of landsliding becomes more important on steep slopes (i.e. $>45$ per cent), whereas incision by Hortonian overland flow is dominant in gentle areas. This trend clearly appears from the integrated dataset collected by Montgomery and Dietrich (1994), shown in Figure 3. In our study, the flattening of the overall negative trend is mainly due to the Lesvos dataset (dataset 7) plotting in the upper part of the scatter plot (Figure 3). This dataset includes gullies initiated by landsliding, as identified from their typical morphology. The influence of landsliding on the initiation of ephemeral gullies in the Guadalentin (datasets 1, 3 and 4) was less obvious from the gully morphology. However, the stony and shallow nature of the Leptosols allows easy saturation of the soil layer and possibly triggers sliding over the bedrock in the concentrated flow zone. 


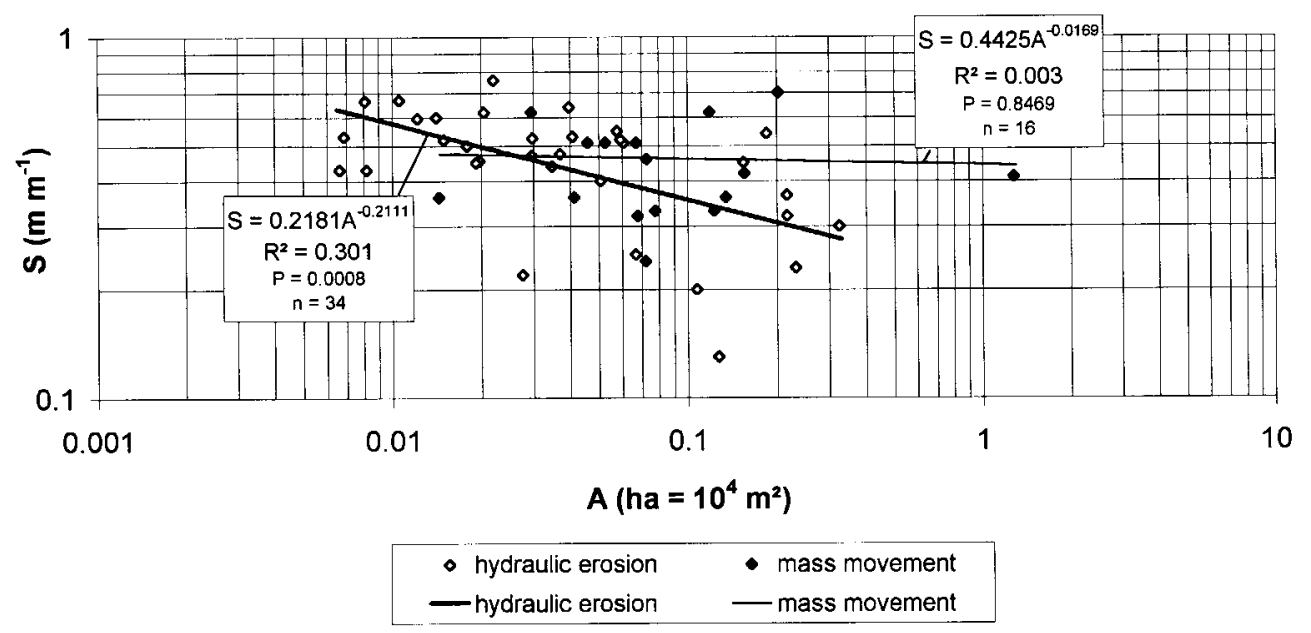

Figure 7. Differentiation of the topographical threshold conditions in Lesvos according to process dominance

Besides the influence of process dominance on the threshold relationship, Figure 3 also illustrates the effect of environmental conditions on the threshold level of the presented datasets. The mean threshold lines of our datasets plot well below the average trend lines through the integrated dataset and the Stanford Hill dataset of Montgomery and Dietrich (1994), and also below the Gungoandra Creek threshold line of Prosser and Abernethy (1996). The cited datasets cover a wide range of climates with average annual rainfall amounts of $260 \mathrm{~mm}$ to $1500 \mathrm{~mm}$ for the datasets of Montgomery and Dietrich (1994), and $500 \mathrm{~mm}$ in Gungoandra Creek (Prosser and Abernethy, 1996). These climatic conditions overlap with those in our study areas (Table I). Lower topographical threshold levels for gully initiation are expected in wetter conditions and higher threshold levels in drier conditions (Montgomery and Dietrich, 1988). However, this principle does not apply when comparing our data with those of the cited studies since some of our study areas, such as the Sierra de Gata $\left(P_{\text {annual }}=182 \mathrm{~mm}\right)$, have a lower annual rainfall than some of the cited study areas, such as Gungoandra Creek $\left(P_{\text {annual }}=500 \mathrm{~mm}\right)$. Consequently, the relative position of the threshold lines cannot be attributed only to the climatic factor. From a comparison of the vegetation type and cover in the different study areas, this factor seems to overrule the effect of climate. The cited datasets of Montgomery and Dietrich (1994) were collected in areas with a protective vegetation cover of grasslands or woodlands, and the gullies in the Gungoandra catchment were formed under a degraded grass cover (Prosser and Abernethy, 1996). Between these datasets, climate does play a differentiating role and threshold levels do increase with decreasing annual rainfall (Montgomery and Dietrich, 1988). From our datasets collected in rangelands, only the gullies in Lesvos (dataset 7) were formed under a vegetation cover of shrubs and grass comparable to that in the cited study areas. This dataset shows the highest threshold level of all our datasets, and plots closest to the average trend line through the integrated dataset of Montgomery and Dietrich (1994) (Figure 3). The more degraded conditions of the vegetation cover in Lesvos (due to grazing and burning) compared to the dense grass cover and root mat in the study areas of Montgomery and Dietrich (1994) explain why the gullies in Lesvos were initiated at local slopes lower than the threshold slope for landsliding of 45 per cent, resulting in a somewhat lower threshold level. In the other study areas with rangelands (dataset 6 in the Sierra de Gata, dataset 8 in the Alentejo), aerial photographs indicated that the gullies were initiated when the fields were still cultivated or just after abandonment, implying a poor vegetative protection. Under these conditions, the threshold level for gully incision is lower than would be expected from the present vegetation cover, and is comparable to that in cultivated fields. The importance of land use and vegetation cover also appeared from a comparison between topographical threshold levels for gully initiation in a variety of environments by Poesen et al. (1998a).

In contrast, the average trend line through the Humboldt range data of Montgomery and Dietrich (1994) plots much closer to our threshold lines. The relationships provided by Harvey (1987) can be considered as an 

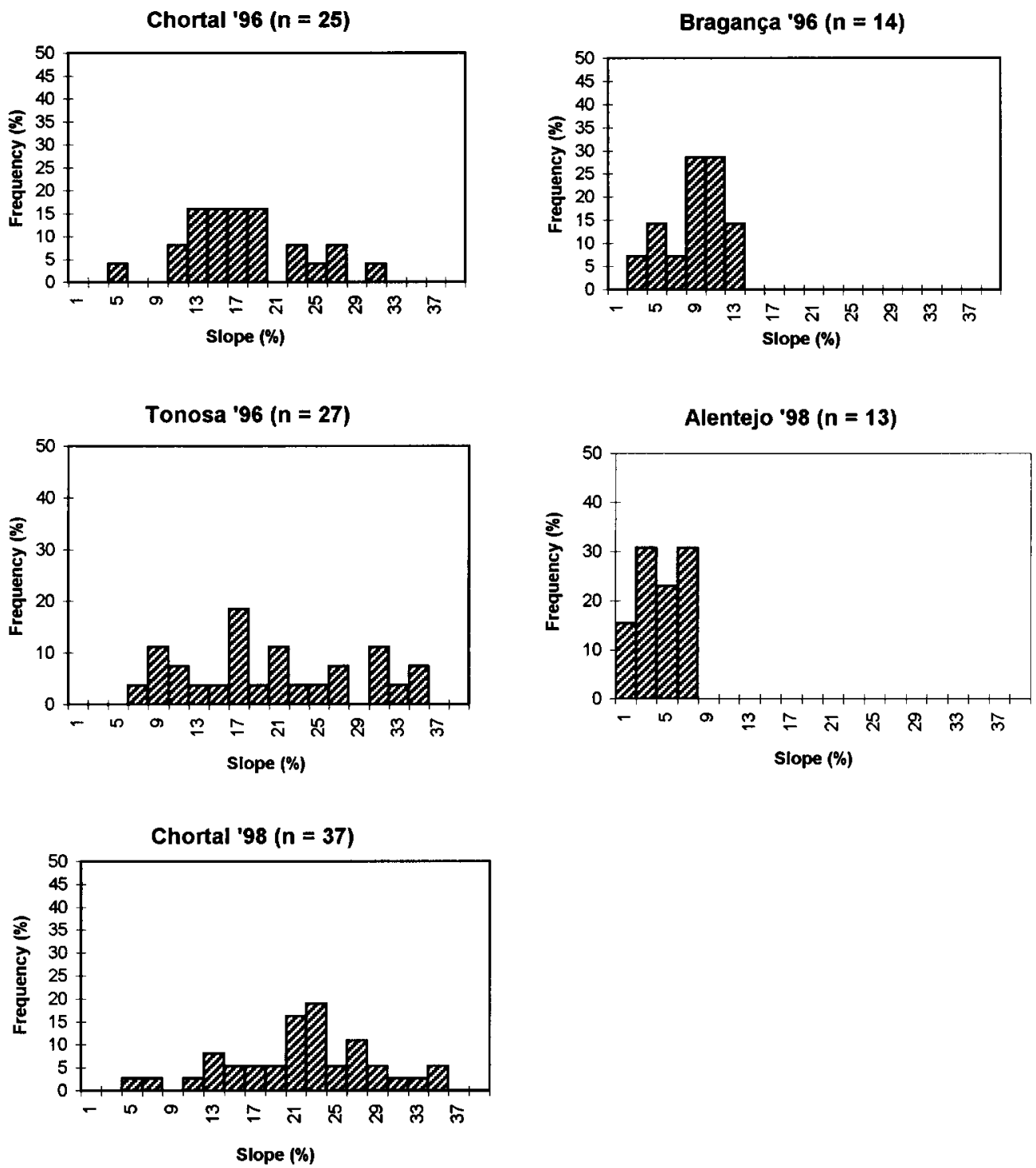

Figure 8. Topographically controlled sedimentation slopes of the studied ephemeral gullies in intensively cultivated areas of the Mediterranean

extension of the trend appearing from our integrated dataset in the lower slope and higher drainage-basin area range. The cited datasets represent channel incision into alluvial fans in an arid region (Humboldt range) and in a semi-arid region (southeast Spain). The poor vegetation cover as well as the climate are similar to the environmental conditions in most of our study areas, in particular the Sierra de Gata area (dataset 6). Hence, both factors explain the relatively small difference in threshold levels.

Although a general trend can be derived from the integrated data cluster, a wide scatter exists and a closer look at the individual datasets reveals some important differences in $S-A$ relationships and threshold levels. Therefore, these differences and their relationship with measured environmental conditions in the individual study areas are the subject of the following discussion. Because of the complex interplay of several factors including land use, climate and soil parameters, an a priori distinction between datasets collected in rangelands and in cultivated lands has been made. Within these groups of datasets, the most relevant factors have been considered. 
Gata '96 ( $(n=43)$

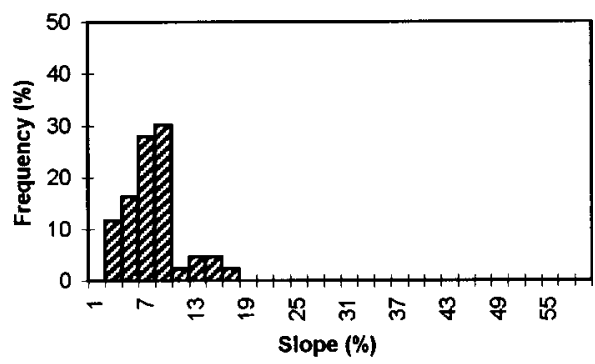

Lesvos ' $97(n=6)$

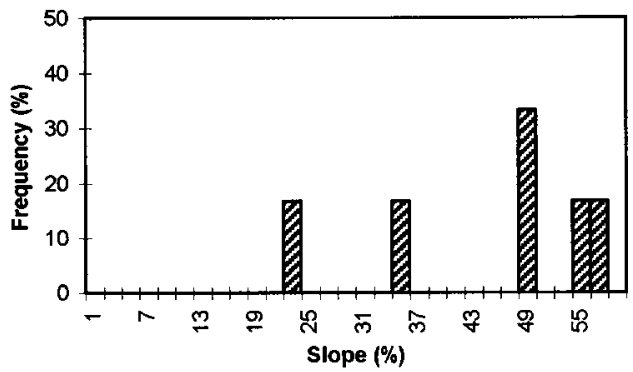

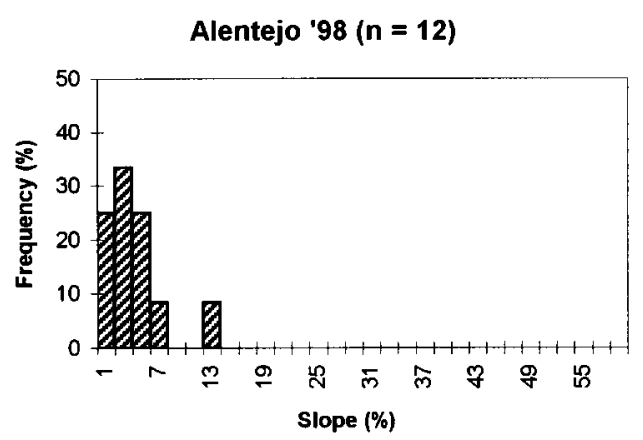

Figure 9. Topographically controlled sedimentation slopes of the studied gullies in rangelands of the Mediterranean

\section{Thresholds for ephemeral gullying in intensively cultivated fields}

Based on the slope ( $b$-value) of the $S-A$ relationships (Table III and Figure 4), a distinction can be made between the datasets collected in the Guadalentin basin (group 1) and those collected in Portugal (group 2), although no statistically significant differences were found. Group 1 consists of datasets 1 (Chortal 1996), 3 (Tonosa 1996) and 4 (Chortal 1998) which have low $b$-values ranging between $0 \cdot 104$ and $0 \cdot 142$. The datasets in group 2 have steeper slopes of the regression lines, i.e. $b=0.226$ for dataset 2 (Bragana 1996), and $b=0.303$ for dataset 5 (Alentejo 1998). According to the theory outlined earlier, this differentiation suggests a difference in process dominance between the Spanish and the Portuguese study areas. Within each group of datasets, soil characteristics, land use and topography in the individual study areas are very similar (Tables I and IV). Hence, the same gully-initiating processes are expected. The range of local slopes $(S)$ at which the ephemeral gullies had been initiated in Portugal is clearly lower than for the datasets collected in the Guadalentin (Figure 4). This reflects the rolling topography in the Portuguese study areas compared to the steep slopes of the Spanish study areas. Soils in Portugal were generally deeper than in the Guadalentin, and contained less rock fragments in the A horizon or at the soil surface (Table IV). Consequently, Hortonian overland flow is dominant in the Portuguese study areas (datasets 2 and 5) whereas the influence of both subsurface flow and incipient landsliding is more important in the Guadalentin (datasets 1, 3 and 4). The latter processes are therefore responsible for the more horizontal position of the topographical threshold relationships in the Guadalentin.

Comparing different threshold levels for ephemeral gully initiation requires rainfall data of the erosion events. In order to minimize the variability in soil and land-use factors, the effect of rainfall was only assessed within the Guadalentin, i.e. for datasets 1 and 4 in the Rambla Chortal, and dataset 3 in the Cerro Tonosa. The threshold line for the Cerro Tonosa clearly plots above the two threshold lines for the Rambla Chortal (Figure 4 ), reflecting its significantly higher intercept ( $a$-value) and implying a higher threshold level. In contrast, the intercept of the threshold line was not significantly different between datasets 1 and 4, suggesting an almost 
a. Rambla Chortal
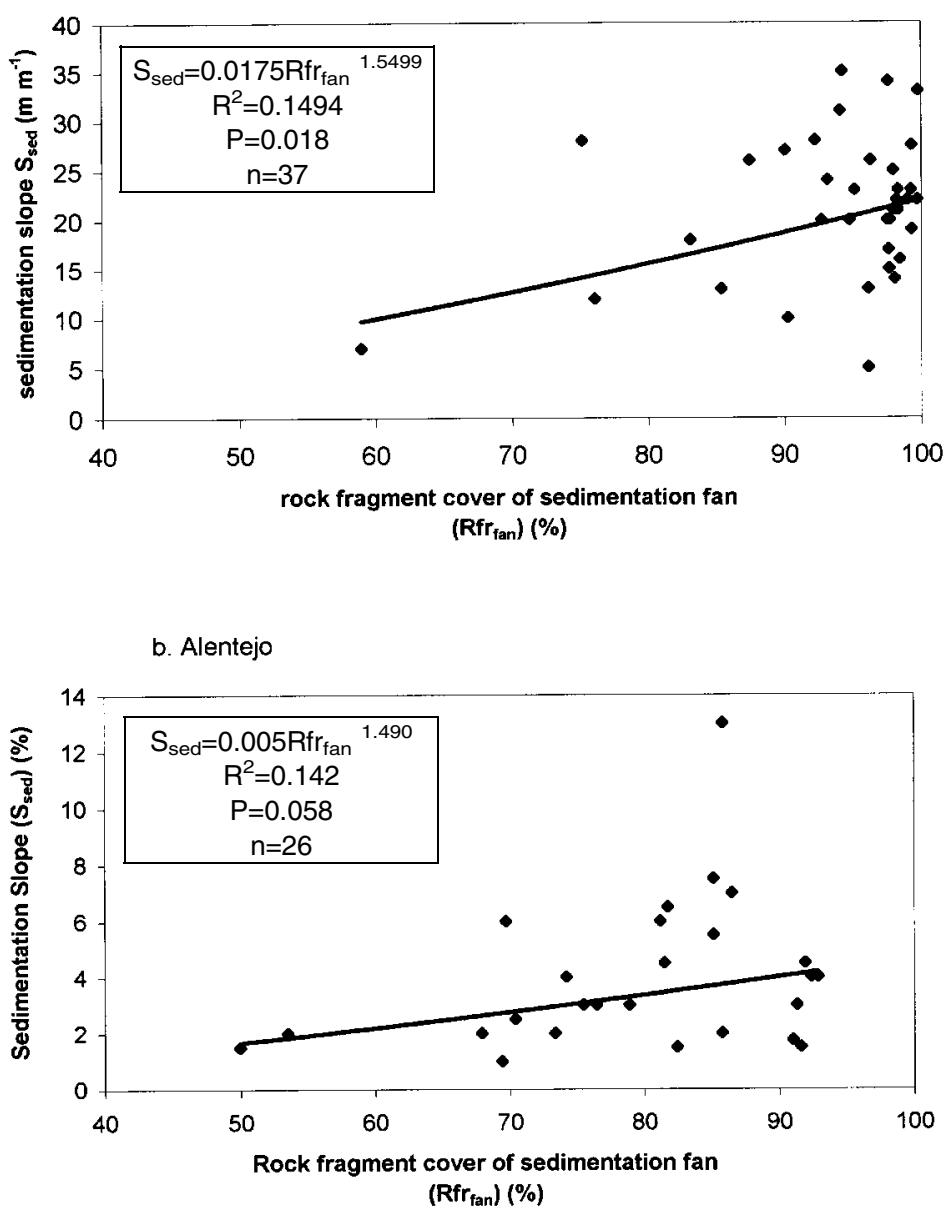

Figure 10. Relation between rock fragment cover of the sedimentation fan $\left(R f r_{\text {sed }}\right)$ and sedimentation slope $\left(S_{\text {sed }}\right)$ in (a) the Rambla Chortal and (b) the Alentejo

identical threshold level for different erosion events within the Rambla Chortal. The significant difference in intercept of the regression line between dataset 1 (Rambla Chortal 1996) and datasets 2 (Bragana 1996) and 5 (Alentejo 1998) does not imply a difference in threshold level because the respective lines cross each other (Figure 4).

According to the rainfall data from all the available sources (Table II), the likely erosion event $\left(P_{\text {gully }}\right)$ in the Rambla Chortal implied a lower rainfall amount in 1995 (dataset 1) and a higher rainfall amount in 1997 (dataset 4). Because other factors including parent material, soil type and land-use are the same for both datasets, the topographical threshold could be expected to be higher in 1995 and lower in 1997. However, the threshold levels of these datasets do not differ significantly. Hence, $P_{\text {gully }}$ cannot explain the relative position of these threshold lines, and other rainfall characteristics must play a role. A plausible explanation is provided by the effects of rainfall distribution before and after the event initiating the ephemeral gullies. Preceding rainfall influences soil structure and soil moisture conditions, and hence the erosion resistance of the soil at the time of incision, whereas after the event, additional rainfall may cause upstream retreat of the gullies. Although the available rainfall data do not include intensities and have not been measured at the gully sites themselves, some general trends appear from the different sources. The cumulative rainfall amount before the erosion event $\left(P_{\text {before}}\right)$ in September 1995 (dataset 1) was less than before September 1997 (dataset 4). But 
daily data from the summer of 1995 show some important peaks shortly after the last tillage operations, whereas the summer of 1997 had only minor daily events between June and August, and the highest rainfall amounts in September. The early events in 1995 may have caused compaction of the topsoil and surface sealing, decreasing the infiltration capacity and increasing runoff production. This may have promoted incision by a relatively small daily rainfall amount in September 1995 but still at the same topographical threshold conditions as in September 1997. The effects of compaction and sealing may have been less in the summer of 1997, so that a higher daily rainfall amount was needed to initiate the ephemeral gullies. In addition, the wet period preceding the probable date of gully initiation in September 1997 may have resulted in higher soil moisture conditions and hence higher resistance to concentrated flow erosion. Flume experiments by Poesen et al. (1999) showed that a given surface rock fragment cover will offer more protection to wet topsoils than to dry topsoils, when the same runoff discharge is applied in both situations. In the field, however, a wet soil may generate more surface runoff than a dry soil, thus compensating its higher erosion resistance. The higher erodibility of a dry soil may be compensated by its higher infiltration capacity and hence retarded surface runoff generation. These interactions are poorly understood for soils with a high rock fragment cover or content in a semi-arid environment, and no related field measurements have been carried out in this study. Hence, the effect of soil moisture remains difficult to assess. Rainfall events that occurred after the initiation of the ephemeral gullies $\left(P_{\text {after }}\right)$ may have caused upstream retreat, lowering the original topographical threshold conditions. For dataset 1, several peaks of higher daily rainfall amounts during the winter of 1995/96 suggest that the gullies formed in September 1995 might have been extended. This would provide an alternative explanation for the low topographical threshold conditions for the initiation of these gullies, as it should be related to higher rainfall amounts later in the season instead of to the relatively low rainfall amounts in September 1995.

The initiation of ephemeral gullies in the Cerro Tonosa (dataset 3) required a higher topographical threshold than in the Rambla Chortal (datasets 1 and 4). As the rainfall amount $\left(P_{\text {gully }}\right)$ in the Cerro Tonosa was lower compared to dataset 4 , but higher compared to dataset 1 , the higher position of the threshold line must be attributed to another environmental factor, such as a higher erosion resistance of the soils. The parent material is the only different characteristic between the two study areas, but it is unlikely that the soils in phylites and quartzites at the Cerro Tonosa are more erosion resistant than those in shales and greywackes in the Rambla Chortal. Both areas are characterized by Leptosols and Regosols showing a high spatial variability in soil textural composition, rock fragment content and cover. From the soil samples taken in both study areas, it can be concluded that variations in topsoil properties within one study area are more important than the difference between the average conditions in the two study areas. In Table IV, the same soil parameter values are also given for both areas. Consequently, the difference in erosion resistance must be related to the rainfall distribution preceding the gully-initiating event. The rainfall pattern during the summer of 1996 (dataset 3) shows a similar pattern to that in 1997 (dataset 4), i.e. no or only a few small events between June and August, and a relatively wet period in the beginning of September. Consequently, the gullies in datasets 3 and 4 may have been initiated in a well structured and wet topsoil, implying a higher erosion resistance compared to the situation in the Rambla Chortal in September 1995 (dataset 1).

\section{Thresholds for gullying in rangelands (abandoned agricultural fields)}

In rangelands, differences in process dominance are also reflected in the different slopes ( $b$-values) of the $S-A$ relationships. The steepest and strongest relationships were obtained from dataset 6 (Sierra de Gata, 1996) and dataset 8 (Alentejo, 1998) (Table III and Figure 5) because soil characteristics (Table IV) in these study areas promote surface runoff rather than subsurface runoff. Between dataset 8 and dataset 7 (Lesvos 1997), the difference in slope was statistically significant. The lower $b$-value and lower correlation coefficient $\left(R_{c}\right)$ of the $S-A$ relationship for Lesvos are mainly attributed to the influence of landsliding on the initiation of gullies included in the dataset. Figure 7 shows that excluding the mass movement sites from the dataset improves and steepens the negative power relationship, reflecting the role of overland flow where hydraulic erosion dominance had been assessed in the field. The subdataset consisting of mass-movement sites resulted in a non-significant and almost horizontal $S-A$ relationship reflecting the combined effect of subsurface flow, 
seepage erosion and landsliding. From Figure 7, it can be concluded that mass movements in Lesvos occur at sites with $S>0.30$ irrespective of drainage-basin area $(A)$.

Figure 5 clearly illustrates that a higher topographical threshold level for gully initiation is required in Lesvos compared to the Sierra de Gata and the Alentejo, as expressed by the significantly higher intercept of the $S-A$ relationship of dataset 7 (Lesvos 1997; Table III). Considering average annual rainfall amounts in the study areas (Table I), both the driest (Sierra de Gata) and the wettest (Alentejo) climates result in the lowest and almost identical threshold levels, whereas the Lesvos area, with an average annual rainfall in between, has the highest threshold level. Consequently, the relative position of the threshold lines presented here cannot be explained entirely by long-term climatic influence.

The high threshold level for gully initiation in Lesvos can be best explained by the relatively high resistance to erosion due to the protective vegetation cover. Although this study area is under intensive sheep grazing, a relatively dense vegetation cover and root mat of shrubs and grasses protected the soil at the time of gully incision, in contrast to the other study areas in rangelands. Statistical analysis of the Lesvos dataset showed that a high vegetation cover in the catchment tends to increase the topographical threshold level for sites with hydraulic erosion dominance (Figure 6a). This effect was less clear in the Sierra de Gata (Figure 6b) because the actual vegetation cover does not reflect the conditions at the time of incipient gullying, i.e. under cultivation or just after abandonment. Also in the Alentejo, the actual vegetation cover established after gully initiation. Because there was little variation in total vegetation cover between the gully catchments in the Alentejo, its effect was not tested for this area. However, differences in vegetation composition, reflecting the time since abandonment of the agricultural fields, appeared to influence the topographical threshold conditions. It was found that sites with a higher density of Cystus, which had been abandoned for a longer time, plotted higher in the $S-A$ datacloud compared to recently abandoned fields where the tillage marks were still visible and almost no Cystus had developed.

Soil parameters (Table IV) provide little additional explanation for the relative position of the threshold lines in rangelands. Soil texture varies little between Lesvos and the Alentejo. Compared to these study areas, the soils in the Sierra de Gata contain less sand but more silt and clay, indicating a higher erodibility. This can partly explain the lower topographical threshold in the Sierra de Gata compared to Lesvos, but not the identical threshold conditions in the less erodible soils of the Alentejo. A protective effect is expected from rock fragments resting on the soil surface (Poesen et al., 1998b). Investigating the effect of the measured rock fragment cover within each study area suggested that this parameter tends to increase the threshold level in the Sierra de Gata, as shown for the Bragana dataset by Vandekerckhove et al. (1998). The effect was less pronounced in Lesvos and not found in the Alentejo. Comparing the different study areas, the average rock fragment cover measured in Lesvos ( 20 per cent) is considerably lower than in the Sierra de Gata (56 per cent) and in the Alentejo (58 per cent). Hence, this parameter does not help explain the relative position of the threshold lines in rangelands. For the Sierra de Gata, however, the measured values for this parameter do not take into account the large embedded rock fragments in the upper Stipa zones. These are expected to increase runoff generation (Poesen and Bunte, 1996). The higher flow shear stress onto the abandoned fields probably helps to overcome the protection by the (measured) rock fragment cover, and hence partly explains the low topographical threshold for gully initiation in the Sierra de Gata.

Besides vegetation and soil parameters underlying the differences in sensitivity to gully erosion between the study areas, the time since the initiation of the gullies may also influence the position of the threshold lines. In the Sierra de Gata and in the Alentejo, the gullies have been initiated shortly after abandonment and may have retreated over time. This causes a downward shift of the topographical threshold line proportional to the time since gully initiation. Because the fields in the Sierra de Gata have been abandoned for a longer time (about 40 years), a more important gully retreat may compensate for the dry climatic conditions compared to the fields in the Alentejo which have not been abandoned for more than one decade but have been prone to a wetter climate. Consequently, the threshold lines may have shifted closer to each other. In the Lesvos study area, there has never been cultivation and the time of gully initiation is not known. 


\section{Threshold slopes for sedimentation}

The frequency distributions of sedimentation slopes in cultivated fields (Figure 8) show that the deposition of sediment load in the concentrated flow occurs at relatively steep slopes in the Spanish study areas (up to 35 per cent) and at lower slopes in the Portuguese study areas (up to 13 per cent). For rangelands (Figure 9), low sedimentation slopes have been measured in the Sierra de Gata (up to 17 per cent) and in the Alentejo (up to 13 per cent), compared to very high slopes in Lesvos (between 23 and 57 per cent). The difference in sedimentation slopes between the Spanish and Portuguese study areas (cultivated lands) is attributed to a corresponding difference in rock fragment content of the topsoils (Table IV) and hence of the sediment which is transported by the gully flow. This coarse load can be transported on steep hillslopes, but a slight decrease in local slope of the soil surface is enough to cause massive sedimentation. A positive relationship between the rock fragment content at the apex of the sedimentation fan and the slope angle at this location has been found for the gullies in Rambla Chortal (dataset 4) and in the Alentejo (datasets 5 and 8) (Figure 10). This is in line with previously reported field data by Poesen et al. (1998a). They reported sedimentation slopes ranging between 0 and 6 per cent for non-stony loess soils in central Belgium, and between 0 and 14 per cent for rangelands containing rock fragments in southeast Spain. The effect of grain size is also reflected in the colluviation model of De Ploey (1984). This could be observed in the Alentejo, where sedimentation often occurred gradually along the channel: larger rock fragments were found at the lower end of the channel bed whereas the actual sedimentation fan, enriched with fines, was found more downslope at lower slope angles.

\section{CONCLUSIONS}

Topographical threshold conditions for the initiation and sedimentation of ephemeral gullies in intensively cultivated fields and of permanent gullies in rangelands have been established for six different Mediterranean study areas. Field measurements of local slope of the soil surface $(S)$ and drainage-basin area $(A)$ at the gully initiation points were plotted as a negative power relationship of the form $S=a A^{-b}$ for each dataset, representing the mean topographical threshold conditions for the respective study area. Compared to theoretical relationships for channel initiation by overland flow, relatively low values for $b$ are obtained, i.e. $0.104<b<0.303$ for intensively cultivated fields, and $0.13<b<0.414$ for rangelands. This suggests the interaction of different processes, dominated by overland flow and influenced by subsurface flow. The influence of landsliding at steeper slopes appeared from the flattening of the overall negative trend in the higher slope range $(S>0 \cdot 30)$ of the integrated dataset. Comparing the threshold lines of our datasets to the average trend lines through data found in literature revealed that vegetation type and cover could better explain differences in topographical threshold level than climatic conditions, corroborating findings by Poesen et al. (1998a).

The wide scatter of the integrated data cluster is due to differences between the $S-A$ relationships and threshold levels of the individual datasets. Within the datasets for cultivated fields, the three Spanish datasets have been distinguished from the two Portuguese datasets based on the slope ( $b$-values) of the $S-A$ relationship. The more horizontal position of the Spanish threshold lines is attributed to a stronger influence of subsurface flow, favoured by the thinner and stonier soils overlying bedrock compared to the Portuguese sites. Seepage erosion and landsliding are potentially active processes interfering with the action of Hortonian overland flow. Amongst the Spanish datasets, collected at different dates in the same or very similar study areas, differences in threshold level cannot be explained by daily rainfall amounts of the events responsible for the initiation of the gullies. They are probably related to differences in soil structure and soil moisture conditions as determined by the rainfall distribution since the date of the last tillage operation until the date of the gully-initiating event. Upstream retreat of the ephemeral gullies by post-event rainfall amounts may also play a role.

For rangelands, the Lesvos dataset results in a lower $b$-value and a higher threshold level compared to the datasets from the Sierra de Gata and the Alentejo. The lower slope ( $b$-value) of the Lesvos dataset is attributed to the influence of subsurface flow, triggering seepage erosion and landsliding. Gullies initiated by mass movements were also observed in the field and included in the dataset. On the contrary, Hortonian overland flow is assumed to be the dominant process in the Sierra de Gata and in the Alentejo. The difference in 
threshold levels cannot be explained by mean annual rainfall amounts but is best explained by the vegetation cover in the gully catchments at the time of incision. This conclusion is consistent with the findings of Prosser and Slade (1994) and Prosser and Abernethy (1996), that surface resistance is more important for gully initiation than the magnitude of events. Further analysis showed that soil erodibility parameters (soil texture and rock fragment cover) are not systematically related to the position of threshold lines. Finally, the time since abandonment of the fields may play a role, as gullies may have retreated in the course of time, lowering the topographical threshold level.

Sedimentation slopes where the studied ephemeral and permanent gullies end are generally high, and this is attributed to the high rock fragment content of the transported sediment. However, both slope and flow discharge determine the transport capacity of a gully flow. Hence, more research is needed to determine critical combinations of slope and drainage-basin area (as a substitute for discharge) as a function of the rock fragment content of the transported and deposited sediment. This would provide a better base for predicting where gullies end than the sedimentation slopes measured in this study.

\section{ACKNOWLEDGEMENTS}

This research was carried out as part of the MEDALUS (Mediterranean Desertification and Land Use) collaborative research project. MEDALUS was funded by the European Commission Environment and Climate Research Programme (contract ENV4-CT95-0118, Climatology and Natural Hazards) and the support is gratefully acknowledged. This study is also a contribution to the Soil Erosion Network of the Global Change and Terrestrial Ecosystems Core Research Programme, which is part of the International Geosphere-Biosphere Programme. Thanks are due to Corinna Hawkes and Julie Shannon (King's College, London), Hein Prinsen (University of Amsterdam), Clare Goodess and Jean Palutikof (Climate Research Unit of the University of East Anglia, UK) for providing rainfall data.

\section{REFERENCES}

Andrade JLA. 1990. Atlas fitoclimatico de España, Taxonomias. Instituto Nacional de Investigations Agrarias, Ministerio de Agricultura Pesca y Alimentation: Madrid.

Begin ZB, Schumm SA. 1979. Instability of alluvial valley floors: a method for its assessment. Transactions of the ASEA 22: 347-350.

Berael C. 1994. Ruimtelijke spreiding van gesteentefragmenten en hun invloed op geul- en ravijnerosie in zuidoost Spanje. MSc thesis, Department of Geography, Katholieke Universiteit Leuven, Belgium.

Boer MM. 1999. Assessment of Dryland Degradation. Linking theory and practice through site water balance modelling. PhD thesis, Faculty of Geographical Sciences, Utrecht University, The Netherlands.

Brice JB. 1966. Erosion and deposition in the loess mantled Great Plains. Medicine Creek drainage basin, Nebraska. US Geological Survey Professional Paper 352 H: 235-339.

Bull LJ, Kirkby MJ, Shannon J, Hooke JM. 1999. The impact of rainstorms on floods in ephemeral channels in southeast Spain. Catena 38: $191-209$.

De Ploey J. 1984. Hydraulics of runoff and loess loam deposition. Earth Surface Processes and Landforms 9: 533-539.

Dietrich WE, Wilson CJ, Reneau SL. 1986. Hollows, colluvium, and landslides in soil-mantled landscapes. In Hillslope Processes, Abrahams AD (ed.). Allen and Unwin: London; 361-388.

Dietrich WE, Wilson CJ, Montgomery DR, McKean J, Bauer R. 1992. Erosion thresholds and land surface morphology. Geology 20: $675-679$.

FAO. 1994. Soil Map of the World. Revised Legend. ISRIC: Wageningen.

Geeson NA, Thornes JB. 1996. Mediterranean Desertification and Land-Use, Executive Summary Phase II. Commission of the European Communities, Directorate General XII Science, Research and Development.

Harvey AM. 1987. Patterns of Quaternary aggradational and dissectional landform development in the Almeria Region, southeast Spain: a dry-region, tectonically active landscape. Die Erde 118: 193-215.

Jackson, J.E. 1991. A User's Guide to Principal Components. John Wiley: New York; 4-12.

Knisel, W.G. 1980. CREAMS: A field scale model for chemicals, runoff and erosion from agricultural management systems. US Department of Agriculture. Conservation research report no. 26: 474-485.

Montgomery, D.R. and Dietrich, W.E. 1988. Where do channels begin? Nature 336: 232-234.

Montgomery, D.R. and Dietrich, W.E. 1989. Source areas, drainage density and channel initiation. Water Resources Research 25: 1907-1918.

Montgomery, D.R. and Dietrich, W.E. 1994. Landscape dissection and drainage area-slope thresholds. In Process Models and Theoretical Geomorphology. Kirkby MJ (ed.). John Wiley: Chichester; 221-245.

Moore, I.D., Burch, G.J. and Mackenzie, D.H. 1988. Topographic effects on the distribution of surface soil water and the location of ephemeral gullies. Transactions of the ASEA 31(4): 1098-1107.

Nachtergaele, J., Poesen, J., Vandekerckhove, L., Oostwoud Wijdenes, D. and Roxo, M., (in press). Testing the Ephemeral Gully 
Erosion Model (EGEM) for two Mediterranean environments. Earth Surface Processes and Landforms.

O'Loughlin, E.M. 1986. Prediction of surface saturation zones in natural catchments by topographic analysis. Water Resources Research 22: 794-804.

Oostwoud Wijdenes, D., Poesen, J., Vandekerckhove, L., Nachtergaele J. and De Baerdemaeker J. 1999. Gully head morphology and implications for gully development on abandoned fields in a semi-arid environment, Sierra de Gata, Southeast Spain. Earth Surface Processes and Landforms 24: 1-19.

Patton, P.C. 1973. Gully erosion in the semi-arid west. MSc thesis. Colorado State University, Fort Collins.

Patton, P.C. and Schumm, S.A. 1975. Gully erosion, northern Colorado: A threshold phenomenon. Geology 3: 83-90.

Poesen J. and Bunte K. 1996. The effects of rock fragments on desertification processes in Mediterranean environments. In Mediterranean Desertification and Land Use, Brandt CJ, Thornes JB, (eds). John Wiley: Chichester; $247-269$.

Poesen, J. and Hooke, J.M. 1997. Erosion, flooding and channel management in Mediterranean environments of southern Europe. Progress in Physical Geography 21(2): 157-199.

Poesen, J., Vandaele, K. and van Wesemael, B. 1996. Contribution of gully erosion to sediment production in cultivated lands and rangelands. In Proceedings of the Exeter Symposium, July 1996, Erosion and Sediment Yield: Global and Regional Perspectives. IAHS Publication no. 236.

Poesen, J., van Wesemael, B., Govers, G., Martinez-Fernandez, J., Desmet, P., Vandaele, K., Quine, T. and Degraer, G. 1997. Patterns of rock fragment cover generated by tillage erosion. Geomorphology 18: 183-197.

Poesen, J., Vandaele, K. and van Wesemael, B. 1998a. Gully erosion: importance and model implications. In Modelling Soil Erosion by Water. Boardman J, Favis-Mortlock D (eds). NATO ASI Series, Vol I 55. Spinger-Verlag: Berlin.

Poesen, J., van Wesemael, B., Bunte, K. and Solé Benet, A. 1998b. Variation of rock fragment cover and size along semi-arid hillslopes: a case study from Southeast Spain. Geomorphology 23: 323-335.

Poesen, J., de Luna, E., Franca, A., Nachtergaele, J. and Govers, G. 1999. Concentrated flow erosion rates as affected by rock fragment cover and initial soil moisture content. Catena 36: 315-329.

Prosser, I.P., (in press). Gully erosion, land-use and climate change. In Climate Change and Soil Erosion, Boardman J Favis-Mortlock D (eds). Imperial College Press: London.

Prosser, I.P. and Abernethy, B. 1996. Predicting the topographic limits to a gully network using a digital terrain model and process thresholds. Water Resources Research 32(7): 2289-2298.

Prosser, I.P. and Slade, C.J. 1994. Gully formation and the role of valley-floor vegetation, southeastern Australia. Geology 22: 11271130.

Renard, K.G., Laflen, J.M., Foster, G.R. and McCool, D.K. 1994. Modelling soil erosion. In Soil Erosion Research Methods, Lal R (ed.). Soil and Water Conservation Society: Ancony, Iowa; 127-158.

US DA. 1992. Ephemeral Gully Erosion Model (EGEM), User Manual US Department of Agriculture, Soil Conservation Service.

Vandaele K., Poesen, J., Marques da Silva, J.R. and Desmet, P. 1995. Assessment of factors controlling ephemeral gully erosion in Southern Portugal and Central Belgium using aerial photographs. Zeitschrift für Geomorphologie 41(3): $273-287$.

Vandaele K., Poesen, J., Govers, G. and van Wesemael B. 1996. Geomorphic threshold conditions for ephemeral gully incision. Geomorphology 16: 161-173.

Vandekerckhove, L., Poesen, J., Oostwoud Wijdenes, D. and de Figueiredo, T. 1998. Topographical thresholds for ephemeral gully initiation in intensively cultivated areas of the Mediterranean. Catena 33: 271-292.

Walter, H. and Lieth, H. 1960. Klimadiagramm. Weltatlas. VEB Gustav Fishler Verlag, Jena, Germany. 